\title{
QUANTITATIVE DETERMINATION OF EPHEDRINE HYDROCHLORIDE IN PHARMACEUTICAL INJ ECTIONS BY HIGHLY SEN SITIVE TURBIDIMETRIC AND REVERSED-PHASE COMBINED WITH UFLC METHODS
}

\author{
Jalal N. Jeber ${ }^{1, *}$
}

https://doi.org/10.23939/chcht13.02.269

\begin{abstract}
In this paper, turbidimetric and reversed-phase ultra-fast liquid chromatography (UFLC) methods were described for the quantitative determination of ephedrine hydrochloride in pharmaceutical injections form. The first method is based on measuring the turbidimetric values for the formed yellowish white precipitate in suspension status in order to determine the ephedrine hydrochloride concentration. The suspended substance is formed as a result of the reaction of ephedrine hydrochloride with phosphomolybdic acid which was used as a reagent. The physical and chemical characteristics of the complex were investigated. The calibration graphs of ephedrine were established by turbidity method. While the second method (UFLC) was conducted using the methanol-water $(55+45$, $\mathrm{v} / \mathrm{v}$ ) as the mobile phase with adjusted water $\mathrm{pH} 3.5$. The ephedrine hydrochloride was detected and measured using UV detector at $260 \mathrm{~nm}$. The linearity of ephedrine was obtained in the range of $0.09-0.39 \mathrm{mmol} \cdot \mathrm{l}^{-1}$. The detection limits (LOD) for the ephedrine hydrochloride were found to be 0.4 and $0.0044 \mathrm{mmol} \cdot \mathrm{l}^{-1}$ by turbidity and UFLC, respectively. The developed methods were successfully applied for the quantitative determination of ephedrine hydrochloride in laboratory preparations (standard) and in commercial pharmaceutical injections. The two methods have given relative standard deviations (R.S.D.) in the range of $0.65-1.69 \%$, which indicates reasonable repeatability and high precision of both methods.
\end{abstract}

Keywords: UFLC, ephedrine hydrochloride, turbidity, pharmaceutical preparations.

\section{Introduction}

The IUPAC name of ephedrine (EPH) is (1R, 2S)-2methylamino-1-phenylpropan-1-ol. Ephedrine belongs to

\footnotetext{
${ }^{1}$ Universities of Baghdad, College of Science, Department of Chemistry Al-Jadriya St., Baghdad, Iraq

* jalalanalyticalchemistry@scbaghdad.edu.iq

(C) Jeber J., 2019
}

the sympathomimetics group known as "ephedrines" which includes norephedrine (NEPH), pseudoephedrine (PEPH) and ephedrine (Fig. 1). These compounds can be obtained either by prepared synthetically or extracted from a herb called ephedra, which is very familiar herb in Chinese medicine [1-3]. This herb is considered as one of the oldest herbs which were used for medicine purpose [4]. Ephedrine $(\mathrm{EPH})$ is a sympathomimetic drug and because of its main actions in decongestion of the nasal mucosa in allergic states, stimulation of the central nervous system as well as relaxation of bronchial muscles, this compound is frequently used in pharmaceutical preparations for the treatment of colds, asthma and allergies [5].

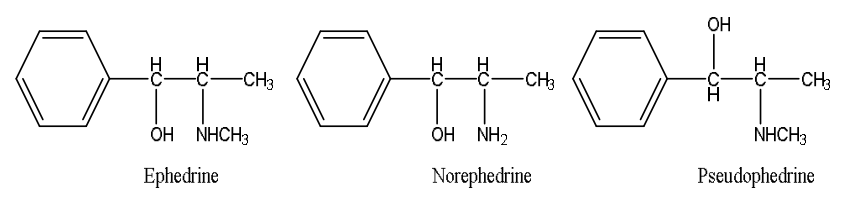

Fig. 1. The ephedrine group

Also, therapeutic doses are used at the level of 15$60 \mathrm{mg}$ to prevent hypotension, catalepsy, and myasthenia gravis and to raise blood pressure. Therefore, developing simple and accurate methods is necessary for the detection and separation of this compound from the pharmaceutical preparations for the routine control analysis. In the literature, several quantitative methods have been presented for the determination of ephedrine in pharmaceutical preparations, including titration technique, which is frequently used to determine pure ephedrine hydrochloride in tablets, aqueous and non-aqueous solutions [6], ratio spectra derivative spectrophotometric [7-9], differential-derivative spectroscopic methods [10, 11], two dimensional-IR [12], capillary electrophoresis [13] and liquid chromatographic analysis (LC) $[14,15]$.

In addition, Boberic-Borojevi has developed an analysis method for simultaneous determination of EPH in tablets in the presence of other active ingredients using 
RP-LC [16]. Not only in tablets, but also, the EPH has been determined in biological fluids (human urine) by several methods such as gas chromatography/mass spectrometric (GC/MS) [17-20], electromembrane extraction coupled with HPLC [21, 22], NMR [23, 24], potentiometry $[25,26]$, high-performance liquid chromatography (HPLC) [27-29], magnetic nanoparticles for solid phase extraction [30], and LC-MS [31, 32].

In this paper, the ephedrine is determined by two methods, the first one is the turbidity, which is based on forming a yellowish white precipitate in suspension status due to the reaction with the phosphomolybdic acid, which is measured by the turbidimetric method. The second method is considered as a novel method, which is based on combining a reverse phase column with ultra-fast liquid chromatography (UFLC). This technique gives a ten times higher speed in comparison with the conventional technique HPLC. Furthermore, UFLC reduces the analytical cyclic time by increasing the speed of sample injection. In addition, UFLC offers a resolution three times higher than the conventional technique HPLC. Based on the literature, for the first time, the ephedrine hydrochloride is determined by turbidity method and UFLC. The proposed methods are fairly accurate, reproducible, rapid and highly sensitive.

\section{Experimental}

\section{1. $M$ aterials}

Pure grade ephedrine hydrochloride was purchased from SVN $®$, Canada. Phosphomolybdic acid $\left(\mathrm{H}_{3} \mathrm{PMo}_{12} \mathrm{O}_{40}\right)$ was obtained from Sigma-Aldrich. Methanol (Sigma-Aldrich) was of analytical grade and all the dilutions were conducted by doubly distilled water. All other chemicals were of analytical reagent grade.

\subsection{Instrumentation and Software}

Turbidity measurements were performed with Hanna Turbidity Benchtop Meter model LP-2000 (Italy). For timing experiments, the heating magnetic stirrer was used to examine the stability of complex with time and heat. For spectroscopic measurements, Shimadzu UVvisible spectrophotometer device model 1800 (Japan) was used. All figures were plotted using Origin Pro 9.1(Microcal) software which allows scientific graphing and interactive data analysis.

\subsection{Turbidity Method}

\subsubsection{General procedure}

A stock standard solution $\left(10 \mathrm{mmol} \cdot \mathrm{l}^{-1}\right)$ of ephedrine hydrochloride was prepared by weight of
$0.533 \mathrm{~g}$ and dissolved in $250 \mathrm{ml}$ using double distilled water. A range of ephedrine concentrations was prepared by further dilution of stock solution by double distilled water. Phosphomolybdic acid (PMA), which was used as a reagent was dissolved in distilled water to give the concentration of $10 \mathrm{mmol} \cdot \mathrm{l}^{-1}$. A series of increasing ephedrine volumes were quantitatively transferred to the set of $10 \mathrm{ml}$ volumetric flasks to constitute the ephedrine within the concentration range of 9.9-0.1 mmol. $\mathrm{l}^{-1}$. Each volumetric flask $(10 \mathrm{ml})$ was then filled to the mark with the phosphomolybdic acid solution $\left(10 \mathrm{mmol} \cdot \mathrm{l}^{-1}\right)$. The solution was shaken at $298 \mathrm{~K}$ for $1 \mathrm{~min}$ and then the values of turbidity were measured. The ephedrine concentration of $3.5 \mathrm{mmol} \cdot \mathrm{l}^{-1}$ had the highest turbidity value and was chosen as the highest concentration can be measured in this experiment which was used for further experiments. The calibration curve for determination of ephedrine hydrochloride was carried out in $10 \mathrm{ml}$ volumetric flasks, each flask contains $6.5 \mathrm{ml}$ of $10 \mathrm{mmol} \cdot \mathrm{l}^{-1}$ of phosphomolybdic acid, which was chosen as the optimum concentration of phosphomolybdic acid (Fig. 2), and $3.5 \mathrm{ml}$ of ephedrine hydrochloride of different concentrations. The mixtures were allowed to shake for one minute at room temperature. The turbidimetric values of the colored mixtures were then recorded and plotted to forming the calibration curve.

\subsubsection{The effect of PMA concentration}

The effect of PMA concentration was investigated in the range of $0.1-9.9 \mathrm{mmol} \cdot \mathrm{l}^{-1}$ for $3.5 \mathrm{mmol} \cdot \mathrm{l}^{-1}$ of ephedrine standard solution. Fig. 2 shows that the turbidity values increase with the increase in the PMA concentration up to $6.5 \mathrm{mmol} \cdot \mathrm{l}^{-1}$. After that, the turbidity values gradually decrease with increased PMA concentration up to $9.9 \mathrm{mmol} \cdot \mathrm{l}^{-1}$ probably due to the increase in the number of precipitate particles and their size. Therefore, $6.5 \mathrm{mmol} \cdot \mathrm{l}^{-1}$ of PMA was chosen as the optimum concentration for the further experiments.

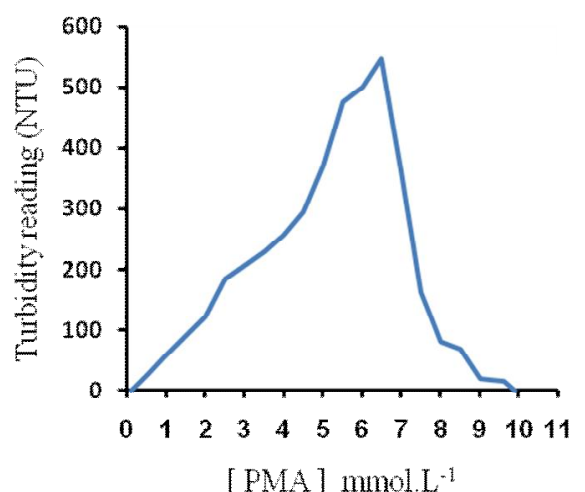

Fig. 2. The effect of reagent concentrations on the turbidity values 


\subsubsection{The effect of $\mathrm{pH}$}

Different concentrations of hydrochloric acid were tested in the range of $2.0-7.0 \mathrm{~mol} \cdot \mathrm{l}^{-1}$. The turbidity values decrease with the increase in $\mathrm{HCl}$ concentration up to $2.0 \mathrm{~mol} \cdot \mathrm{l}^{-1}$. Therefore, it is not preferred to conduct the ephedrine assay in acidic media and $\mathrm{pH} 7.0$ was chosen for the further experiments.

\subsubsection{The colloid protector's effect}

In the turbidimetric methods, the colloidal materials are commonly used to stabilize the solution and avoid the adherence of particles inside the inner walls of cells or tubes. Therefore, two types of colloidals (polyvinyl alcohol and ethylene glycol) have been used and studied with three different concentrations $(0.01,0.02$ and $0.06 \%$, w/v). Each colloidal material was added to the solution (sample and reagent). The results have shown that there is no difference in the turbidimetric values; the values are still the same with or without using the colloidal protectors.

\subsubsection{Temperature effect}

The temperature range of $293-333 \mathrm{~K}$ was investigated to study the formed complex stability. The results show that the stability gradually decreases with the increase in temperature up to $333 \mathrm{~K}$. At this temperature the complex totally disappears and the turbidimetric values are equal to zero, which means that the formed complex is unstable at higher degrees. The best temperature was $298 \mathrm{~K}$, which was used in all experiments as the optimum temperature (Fig. 3).

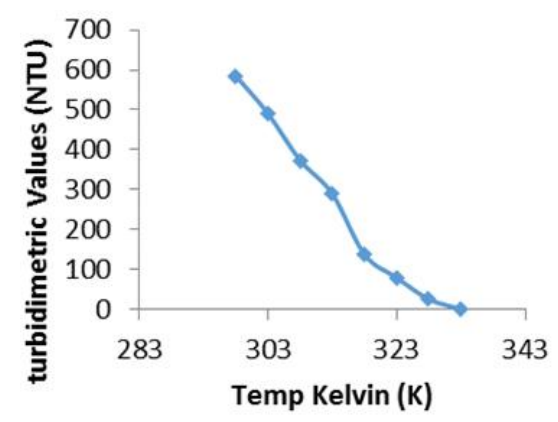

Fig. 3. The temperature effect on the stability of the complex

\subsubsection{Analysis of pharmaceutical injections}

The pharmaceutical injections $(30 \mathrm{mg} / \mathrm{ml})$ were supplied from the local market already dissolved in distilled water. Further dilutions for the injections were carried out to obtain the required concentrations.

\subsection{UFLC Method}

\subsubsection{Conditions}

A reverse column $\mathrm{C} 18(20 \mathrm{~cm} \times 4.6 \mathrm{~mm})$ packed with octadecylsilane silica gel was used to perform all the chromatographic separations. A mixture of methanol+water $(55+45, \mathrm{v} / \mathrm{v})$ with adjusted $\mathrm{pH}$ of water (3.5) by dioctyl sodium sulfosuccinate $\left(6 \mathrm{mmol} \cdot \mathrm{l}^{-1}\right)$ was used as the mobile phase. The analysis of ephedrine and the internal standard solution was carried out using flow rate $1.4 \mathrm{ml} \cdot \mathrm{min}^{-1}$ (isocratic conditions) and the UV detector was used to monitor the effluents at $260 \mathrm{~nm}$. $0.47 \mu \mathrm{m}$ membrane filter and ultrasonic bath were used to filter all solutions and degassed, respectively. All the solutions were injected $(20 \mu \mathrm{m}$ from each solution) and the data were recorded (chromatograms).

\subsubsection{Equipments}

The chromatographic analysis and separation of the samples from the aqueous solutions were carried out by Prominence UFLC (Shimadzu, Japan) equipped with SPD-20A UV-Vis as the detector. All the acquired data were analyzed using Lab Solution DB (Version 6.5). A stainless steel column C18 $(20 \mathrm{~cm} \times 4.6 \mathrm{~mm})$ packed with octadecylsilane silica gel was used to separate the samples under the experimental conditions.

\subsubsection{Analysis of injections}

Further dilutions to the injection were carried out using the mobile phase and the internal standard solution.

\section{Results and Discussion}

\subsection{Turbidity Method}

\subsubsection{The calibration curve and application}

The calibration curve for the ephedrine was linear in the concentrations which are ranged from 0.7 to $3.9 \mathrm{mmol} \cdot \mathrm{l}^{-1}$ (Table 1) with the limit of detection $4.0 \cdot 10^{-4} \mathrm{M}$. The relative standard deviation (R.S.D.) of ephedrine hydrochloride $\left(2.5\right.$ and $\left.3.5 \mathrm{mmol} \cdot \mathrm{l}^{-1}\right)$ were found to be less than $1.7 \%(n=6)$, which indicates reasonable repeatability and high precision of the method (Table 2). The regression equation of the calibration curve was $Y=180.49 x-$ $-151.91 ; r=0.9915$, whereas $x$ is the concentration of ephedrine and $Y$ is the turbidity value. The developed turbidimetric method under the above optimized experimental conditions was successfully applied to determine the ephedrine in the pharmaceutical injections. The results of ephedrine analysis in the commercial injections are presented in Table 3. The determinations of ephedrine were conducted in triplicate for each sample injection using standard addition method and the results were mathematically treated. 
The summary of linear calibration graph

\begin{tabular}{|c|c|c|c|c|c|}
\hline $\begin{array}{l}\text { Measured } \\
\text { range, } \mathrm{mmol} \cdot \mathrm{l}^{-1}\end{array}$ & $\begin{array}{l}\text { Linear range, } \\
\mathrm{mmol} \cdot \mathrm{l}^{-1}\end{array}$ & Regression equation & $\begin{array}{c}\text { Correlation coefficient } \\
R, \\
\text { The coefficient of } \\
\text { determination } R^{2}\end{array}$ & $\begin{array}{c}t_{\text {tab. }} \\
\text { (theoretical) }\end{array}$ & $\begin{aligned} t_{c a l} & =\frac{|r| \sqrt{n-2}}{\sqrt{1-r^{2}}} \\
\text { (from the } & \text { experiment) }\end{aligned}$ \\
\hline & & & & \multicolumn{2}{|c|}{ at $95 \%, n-2$} \\
\hline $0.5-4.0$ & $\begin{array}{c}0.7-3.5 \\
(n=9)\end{array}$ & $\begin{array}{c}Y=180.49 x-151.91[\mathrm{EPH}] \\
\mathrm{mmol} \cdot \mathrm{r}^{-1}\end{array}$ & $\begin{array}{l}0.9915 \\
0.9832 \\
\end{array}$ & \multicolumn{2}{|c|}{$2.365<<20.24$} \\
\hline
\end{tabular}

Table 2

The repeatability results for the ephedrine hydrochloride

\begin{tabular}{|c|c|c|c|c|c|}
\hline $\begin{array}{c}{[\mathrm{EPH}], \mathrm{mmol}_{1}^{-} \mathrm{I}^{-}} \\
\text {measuring } n\end{array}$ & $\begin{array}{c}\text { Average response } \overline{y_{i}} \\
(n=6), \mathrm{mV}\end{array}$ & $\begin{array}{c}\text { Standard } \\
\text { deviation } \\
\sigma_{n-1}\end{array}$ & $\begin{array}{c}\text { Repeatability } \\
\text { R.S.D., } \%\end{array}$ & $\begin{array}{c}\text { Confidence interval of the } \\
\text { mean } \\
\bar{y}_{i} \pm t_{(\alpha=0.05 / 2)}\end{array}$ \\
\hline 2.5 & 6 & 283.42 & 4.79 & 1.69 & $283.42 \pm 4.43$ \\
\hline 3.5 & 6 & 508.28 & 5.21 & 1.02 & $508.28 \pm 4.82$ \\
\hline
\end{tabular}

The obtained results by the turbidimetric method for the ephedrine determination in pharmaceutical injection samples

\begin{tabular}{|c|c|c|c|c|c|}
\hline $\begin{array}{c}\text { Commercial } \\
\text { name } \\
\text { Country }\end{array}$ & $\begin{array}{c}\text { Confidence interval for } \\
\text { average weight at } 95 \% \text {, } \\
\qquad \mathrm{g} \\
\bar{V} \pm 1.96 \frac{\sigma_{n-1}}{\sqrt{n}}\end{array}$ & $\begin{array}{l}\text { Volume of sample, } \mathrm{ml} \\
\text { to obtain } 0.09 \mathrm{mmol} \cdot \mathrm{l}^{-1}\end{array}$ & $\begin{array}{c}\text { Theoretical content } \\
\text { of active ingredient } \\
\text { at } 95 \%, \mathrm{mg} \\
n=\infty\end{array}$ & $\begin{array}{l}\text { Found content of } \\
\text { active ingredient at } \\
\begin{array}{c}95 \%, \mathrm{mg} \\
n=\infty\end{array}\end{array}$ & $\begin{array}{c}\text { Recovery, } \\
\%\end{array}$ \\
\hline $\begin{array}{l}\text { Sample 1, } \\
\text { India }\end{array}$ & $1.045 \pm 0.005$ & $\begin{array}{c}0.5 \mathrm{ml} \\
\text { equivalence to } 15 \mathrm{mg} \\
\text { EPH active ingredient }\end{array}$ & $15.0 \pm 0.021$ & $14.67 \pm 0.034$ & 97.80 \\
\hline $\begin{array}{l}\text { Sample 2, } \\
\text { Jordan }\end{array}$ & $1.041 \pm 0.003$ & $\begin{array}{c}0.5 \mathrm{ml} \\
\text { equivalence to } 15 \mathrm{mg} \\
\text { EPH active ingredient }\end{array}$ & $15.0 \pm 0.041$ & $14.77 \pm 0.024$ & 98.46 \\
\hline
\end{tabular}

\subsection{UFLC Method}

\subsubsection{UFLC calibration}

To plot the calibration graph, triplicate $20 \mu \mathrm{l}$ of ephedrine hydrochloride solutions were injected and the area of peaks of ephedrine was plotted against the prepared concentrations. A stock solution of ephedrine was prepared by dissolving it in methanol to obtain $5 \mathrm{mmol} \cdot \mathrm{l}^{-1}$. The recorded data were used to plot the calibration curve in the range of $0.09-0.37 \mathrm{mmol} \cdot \mathrm{l}^{-1}$ (Table 4). In order to provide a suitable procedure for rapid and simple determination of ephedrine, reversed phase UFLC was adopted, which was used for quality control. A mixture of methanol and water was chosen for the mobile phase. After mixing of various proportions (methanol+water) under different $\mathrm{pH}$ values, the typical separation was obtained using mobile phase, which consists of methanol+water $(55+45, \mathrm{v} / \mathrm{v})$ with $\mathrm{pH} 3.5$. The UV detector was used and the optimum detector response was at $260 \mathrm{~nm}$. The selectivity and tailing factors for the chromatographic system were 1.71 and 1.65 , respectively. At the flow rate of $1.4 \mathrm{ml} \cdot \mathrm{min}^{-1}$, the retention time for the ephedrine was $5.1 \mathrm{~min}$, as shown in Fig. 4. The studies of ephedrine hydrochloride samples within the same day and between the days were carried out. The results show that the assay has a high accuracy, reproducibility and can conduct at any time without any significant difference between the days or within the same day (Table 5). 
Fig. 4. The typical chromatogram of pharmaceutical injection sample which contains ephedrine hydrochloride

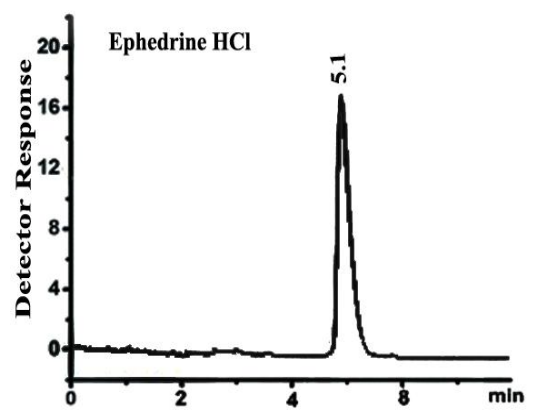

Table 4

The statistical analysis of UFLC method for determination of ephedrine hydrochloride

\begin{tabular}{|c|c|c|c|c|c|c|c|}
\hline Analyte name & $\begin{array}{c}\text { Wavelength, } \\
\mathrm{nm}\end{array}$ & $\begin{array}{c}\text { Range of } \\
\text { linearity, } \\
\mathrm{mmol} \cdot \mathrm{l}^{-1}\end{array}$ & $\begin{array}{c}\text { Regression } \\
\text { equation }\end{array}$ & $\begin{array}{c}\text { Correlation } \\
\text { coefficient }\end{array}$ & $\begin{array}{c}\text { R.S.D., } \\
\%\end{array}$ & $\begin{array}{c}\text { Detection } \\
\text { limit, } \mathrm{mmol}_{1} \mathrm{l}^{-}\end{array}$ & $\begin{array}{c}\text { Quantitation } \\
\text { limit, } \mathrm{mmol} \cdot \mathrm{l}^{-1}\end{array}$ \\
\hline $\begin{array}{c}\text { Ephedrine } \\
\text { hydrocloride }\end{array}$ & 260 & $0.09-0.37$ & $\begin{array}{c}Y=0.014 C- \\
0.1344\end{array}$ & 0.998 & 0.84 & 0.0044 & 0.014 \\
\hline
\end{tabular}

Table 5

Precision of ephedrine by UFLC method between the days and within the same day

\begin{tabular}{|c|c|c|c|c|c|c|}
\hline \multirow{2}{*}{$\begin{array}{c}\text { Theoretical } \\
\text { concentration of } \\
\text { ephedrine, } \mathrm{mmol} \cdot \mathrm{l}^{-1}\end{array}$} & \multicolumn{3}{|c|}{$\begin{array}{l}\text { Measured concentration within the same day, } \\
\mathrm{mmol} \cdot \mathrm{l}^{-1}\end{array}$} & \multicolumn{3}{|c|}{ Measured concentration per one week, $\mathrm{mmol} \cdot \mathrm{l}^{-1}$} \\
\hline & $\begin{array}{l}\text { Mean } \\
N=6\end{array}$ & $\begin{array}{c}\text { Standard } \\
\text { deviation } \\
\sigma_{n-1}\end{array}$ & $\begin{array}{c}\text { R.S.D., } \\
\%\end{array}$ & $\begin{array}{l}\text { Mean } \\
N=6\end{array}$ & $\begin{array}{c}\text { Standard } \\
\text { deviation } \\
\sigma_{n-1}\end{array}$ & $\begin{array}{c}\text { R.S.D., } \\
\%\end{array}$ \\
\hline 0.2 & 0.201 & 0.0014 & 0.73 & 0.2016 & 0.0019 & 0.98 \\
\hline 0.3 & 0.3021 & 0.0019 & 0.65 & 0.3025 & 0.0028 & 0.93 \\
\hline
\end{tabular}

Table 6

The recoveries of ephedrine hydrochloride from commercial pharmaceutical samples

\begin{tabular}{|c|c|c|c|}
\hline \multirow{2}{*}{ Sample No } & \multicolumn{2}{|c|}{ Ephedrine hydrochloride, mmol $\cdot 1^{-1}$} & \multirow{2}{*}{ Recovery, $\%$} \\
\cline { 2 - 4 } & Added & Found & 97.3 \\
\hline Sample 1 & 0.15 & 0.146 & 99.2 \\
\hline Sample 1 & 0.25 & 0.248 & 103.3 \\
\hline Sample 2 & 0.15 & 0.155 & 98.4 \\
\hline Sample 2 & 0.25 & 0.246 & \\
\hline
\end{tabular}

\subsubsection{Methods validation and applicably}

The validation and the application of the proposed UFLC method were assessed by performing the recovery study. The recoveries from the pharmaceutical commercial samples were carried out by adding two different concentrations of ephedrine to each sample. The recovery percentages were $97.3-103.3 \%$ of ephedrine from samples. The obtained recoveries results show that higher recovery percentage $103.3 \%$ indicates no interference of the excipients in the pharmaceutical formulation. Also, it indicates the precision and accuracy of the proposed UFLC method. All the results are tabulated in Table 6 .

\section{Conclusions}

Both analytical methods have been applied successfully on the commercial samples. However, the UFLC method needs expensive materials (column and organic solvents), equipment and sometimes takes very long time of analysis (in this paper, the first run takes $35 \mathrm{~min}$ to obtain the signal). The second method is the turbidity, which has been developed for cheap, rapid, sensitive, and simple analysis of ephedrine hydrochloride in pharmaceutical formulations. This method is easily applied with high accuracy in the presence of interference. Finally, the methods can be used as alternative methods for the determination of ephedrine in pharmaceutical preparations. 


\section{References}

[1] Pharmacopoeia of the People's Republic of China, v.1. 1990.

[2] Liu Y.M., Sheu S.J.: J. Chromatogr. A, 1992, 600, 370. https://doi.org/10.1016/0021-9673(92)85575-E

[3] Mei F., Xing X., Tang Q. et al.: Chinese J. Integrat. Medicine, 2016, 22, 445. https://doi.org/10.1007/s11655-014-1952-x

[4] Wagner H., Bauer R., Melchart D., Staudinger A.: Herba Ephedrae - Mahuang. [in:] Wagner H., Bauer R., Melchart D., Staudinger A. (Eds.), Chromatographic Fingerprint Analysis of Herbal Medicines, v. IV. Springer, Cham, 2016, 107-114. https://doi.org/10.1007/978-3-319-32328-2_11

[5] Abourashed E., El-Alfy A., Khan I., Walker L.: Phytother. Res., 2003, 17, 703. https://doi.org/10.1002/ptr.1337

[6] Pharmacopoeia B., A96, 1972.

[7] Șentürk Z., Erk N., Özkan S. et al.: J. Pharm. Biomed., 2002, 29, 291. https://doi.org/10.1016/S0731-7085(02)00065-1

[8] Abdel-Ghani N., Rizk M., Mostafa M.: Spectrochim. Acta A, 2013, 111, 131. https://doi.org/10.1016/j.saa.2013.03.038

[9] Moustafa A., Hegazy M., Mohamed D., Ali O.: J. AOAC Int., 2018, 101, 414. https://doi.org/10.5740/jaoacint.17-0078

[10] Parimoo P., Umapathi P., Srinivasan K.: Indian Drugs, 1992, 29, 442.

[11] Pascual-Marti M., Marin Saez R., Iranzo Adrian J.: Fresen. J. Anal. Chem., 1995, 352, 396. https://doi.org/10.1007/BF00322242 [12] Miao L., Liu Y., Li H. et al.: Drug Test. Analys., 2017, 9, 221. https://doi.org/10.1002/dta.1963

[13] Mateus-Avois L., Mangin P., Saugy M.: J. Chromatogr. B, 2003, 791, 203. https://doi.org/10.1016/S1570-0232(03)00222-8

[14] An Q., Dong Y., Lu N., Li N.: J. Liq. Chromatogr. R. T., 2017, 40, 177. https://doi.org/10.1080/10826076.2017.1287723

[15] Tircova B., Kozlik P.: Chromatographia, 2017, 80, 523. https://doi.org/10.1007/s10337-016-3170-5

[16] Boberić-Borojević D., Radulović D., Ivanović D., Ristić P.: J. Pharm. Biomed., 1999, 21, 15. https://doi.org/10.1016/S07317085(99)00103-X

[17] Nakano M., Morimoto Y., Tajima S. et al.: J. Pharm. Soc. Japan, 2000, 120, 583.

https://doi.org/10.1248/yakushi1947.120.6_583

[18] El-Haj B., Al-Amri A., Hassan M. et al.: Forensic Sci. Int., 2003, 135, 16. https://doi.org/10.1016/S0379-0738(03)00101-4 [19] Gentili S., Torresi A., Marsili R. et al.: J. Chromatogr. B, 2002 , 780, 183. https://doi.org/10.1016/S1570-0232(02)00522-6

[20] Mohamed K., Al-Hazmi A., Alasiri A., Ali M.: J. Chromatogr. Sci., 2016, 54, 1271. https://doi.org/10.1093/chromsci/bmw082

[21] Fotouhi L., Yamini Y., Molaei S., Seidi S.: J. Chromatogr. A, 2011, 1218, 8581. https://doi.org/10.1016/j.chroma.2011.09.078

[22] Baharfar M., Yamini Y., Seidi S., Karami M.: J. Chromatogr.

B, 2017, 1068, 313. https://doi.org/10.1016/j.jchromb.2017.10.062

[23] Hanna G.: J. AOAC Int., 1995, 78, 946.

[24] Bogun B., Moore S.: Forensic Sci. Int., 2017, 278, 68.

https://doi.org/10.1016/j.forsciint.2017.06.026
[25] Shawish H., Elhabiby M., Aziz H. et al.: Sensor. Actuat. BChem., 2016, 235, 18. https://doi.org/10.1016/j.snb.2016.05.058 [26] Hassan S., Kamel A., El-Naby H.: Talanta, 2013, 103, 330. https://doi.org/10.1016/j.talanta.2012.10.067

[27] Wang J.-W., Chiang M.-H., Lu C.-M., Tsai T.-H.: J.

Chromatogr. B, 2016, 1026, 152.

https://doi.org/10.1016/j.jchromb.2015.12.027

[28] Baharfar M., Yamini Y., Seidi S., Karami M.: J. Chromatogr. B, 2017, 1068, 313. https://doi.org/10.1016/j.jchromb.2017.10.062 [29] Rouhani G., Ertekin Z., Dinç E.: J. Liq. Chromatogr. R. T., 2017, 40, 333. https://doi.org/10.1080/10826076.2017.1300171 [30] Taghvimi A., Hamishehkar H.: J. Chromatogr. B, 2017, 1041, 113. https://doi.org/10.1016/j.jchromb.2016.11.039

[31] Xu J., Yan R.: J. Chromatogr. Sci., 2017, 55, 162. https://doi.org/10.1093/chromsci/bmw165

[32] Kojima A., Nishitani Y., Sato M. et al.: Drug Test. Analysis, 2016, 8, 189. https://doi.org/10.1002/dta.1803

Received: November 31, 2017 / Revised: December 12, 2017 /

Accepted: April 30, 2018

\section{КІЛЬКІСНЕ ВИЗНАЧЕННЯ ГІДРОХЛОРИДУ ЕФЕДРІНУ У ФАРМАЦЕВТИЧНИХ ІН'ЕКЦІЯХ ВИСОКОЧУТЛИВИМ ТУРБИДИМЕТРИЧНИМ МЕТОДОМ І ОБЕРНЕНО-ФАЗНОЮ НАДШВИДКОЮ РІДИННОЮ ХРОМАТОГРАФІЄЮ}

Анотація. За допомогою турбидиметричного методу та обернено-фазної надшвидкої рідинної хроматографії (НРХ) визначено кількість гідрохлориду ефедрину у фармацевтичних ін'єкціях. Периим методом на основі турбидиметричних величин утвореного жовтувато-білого осаду у вигляді суспензіі визначено концентрацію гідрохлориду ефедрину. Суспензія утворюється внаслідок реакиї між гідрохлоридом ефедрину та флуоромолібденовою кислотою, яку використовували як реагент. Досліджено ї̈ фізико-хімічні характеристики та побудовано калібрувальні графіки ефедрину. У другому способі (НРХ) використано рухому фазу метанол-вода (55:45, об.\%; рН води 3,5). Кількість гідрохлориду ефедрину визначали з використанням УФ-детектора при 260 нм. Лінійність ефедрину встановлено в діапазоні 0,09-0,39 миоль $\cdot л^{-1}$, а межса чутливості для турбидиметричного та НРХ методу становила 0,4 та 0,0044 ммоль $\pi^{-1}$, відповідно. Показано, що розроблені методи можсна успішно застосовувати для кількісного визначення гідрохлориду ефедрину в лабораторних препаратах (стандарт) та комериійних фармащевтичних ін'єкиіях. Відносні стандартні відхилення обох методів знаходяться в інтервалі 0,65-1,69\%, щзо вказує на коректну відтворюваність і високу точність методів.

Ключові слова: обернено-фазна надшвидка рідинна хроматографія, гідрохлорид ефедрину, турбидиметрія, фармачевтичні препарати. 